\title{
Oxidative stress in cervical cancer and its response to chemoradiation
}

\section{Rahim ağzı kanserinde oksidatif stres ve kemoradyasyon yanitı}

\author{
(D) Saiqa Shah1,2, (1) Bhuvanesh Sukhlal Kalal1,3 \\ 1 Yenepoya (Deemed to be University), Yenepoya Medical College, Department of Biochemistry, Mangaluru, India \\ ${ }^{2}$ Vydehi Institute of Medical Sciences and Research Centre, Department of Biochemistry, Bengaluru, India \\ ${ }^{3}$ A. J. Institute of Medical Sciences and Research Centre, A. J. Research Centre, Mangaluru, India
}

\begin{abstract}
Objectives: Cervical cancer $(\mathrm{CaCx})$ is one of the leading causes of cancer-related death among women worldwide, with the great social and economic burden. Diagnoses in early stages can decrease mortality and morbidity rates. This study was conducted to evaluate the status of serum total antioxidant capacity (TAC), and malondialdehyde (MDA) and copper concentrations among patients with $\mathrm{CaCx}$ to determine the level of oxidative stress and effect on which of chemoradiation.

Materials and Methods: Fifty patients with histopathologically proven $\mathrm{CaCx}$ who visited the department of oncology \& gynaecology and 50 age-matched healthy females were selected for the study. Serum TAC, MDA, and copper were estimated in both study groups. The effect of chemoradiation on these was estimated in patients with $\mathrm{CaCx}$.

Results: The mean \pm standard deviation age of the patients was $43.98 \pm 6.38$ years, whereas that of the controls was $31.56 \pm 6.84$ years. The mean serum copper and MDA concentrations in the patients was significantly higher as compared with the controls, whereas the mean TAC in the patients was reduced when compared with the controls. After chemoradiation, there was a significant increase and decrease in TAC and MDA, respectively, after chemoradiotherapy, whereas the changes in the copper concentrations were insignificant.

Conclusion: These results suggest that patients with $\mathrm{CaCx}$ were in oxidative stress because the oxidative parameters in serum (copper, MDA) were increased and the defensive TAC was decreased in patients with $\mathrm{CaCx}$ and chemoradiotherapy improved their anti-oxidant capacity. Further studies are needed to evaluate the concurrent use of antioxidants with chemoradiotherapy for improving the disease prognosis.
\end{abstract}

Keywords: Cervical cancer, copper, malondialdehyde, total antioxidant capacity, chemoradiation

$\ddot{O} z$

Amaç: Büyük bir sosyal ve ekonomik yükü olan rahim ağzı kanseri, dünya genelindeki kadınlar arasında kansere bağlı ölümlerin önde gelen nedenlerinden biridir. Erken evrelerdeki tanısı, mortalite ve morbidite oranlarını azaltabilmektedir. Bu çalısma, oksidatif stres düzeyini ve kemoradyasyonun etkisini belirlemek için rahim ağzı kanserli hastalarda serum total antioksidan kapasitesi (TAK) ile malondialdehit (MDA) ve bakır konsantrasyonlarının durumunu değerlendirmek amaciyla yapıldı.

Gereç ve Yöntemler: Onkoloji ve jinekoloji anabilim dalına başvuran, histopatolojik olarak rahim ağzı kanseri olduğu kanıtlanmış 50 hasta ve yaş-uyumlu 50 sağlıklı kadın çalışma için seçildi. Her iki çalışma grubunda da serum TAK, MDA ve bakır değerleri ölçüldü. Kemoradyasyonun bunlar üzerindeki etkisi rahim ağzı kanserli hastalarda değerlendirildi.

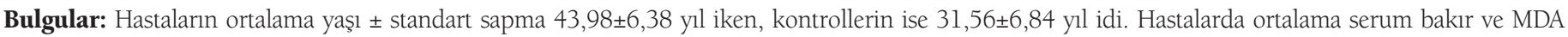
konsantrasyonları kontrollerle karşılaştırıldığında anlamlı derecede yüksek iken, ortalama TAK değeri kontrollere göre azaldı. Kemoradyoterapi sonrasında sırasıyla TAK ve MDA'da anlamlı bir artış ve azalma mevcuttu, bakır konsantrasyonundaki değişiklikler ise anlamlı değildi.

Sonuç: Bu bulgular; rahim ağzı kanserli hastaların oksidatif stres içerisinde olduklarını, çünkü bu hastalardaki serum oksidatif parametrelerin (bakır, MDA) arttığını ve koruyucu TAK’nin azaldığını ve kemoradyoterapinin antioksidan kapasitelerini artırdığını göstermektedir. Hastalık prognozunu iyileştirmede, antioksidanların kemoradyoterapi ile eş zamanlı kullanımını değerlendirmek için ileri çalışmalara gereksinim duyulmaktadır.

Anahtar Kelimeler: Rahim ağzı kanseri, bakır, malondialdehit, total antioksidan kapasite, kemoradyasyon

PRECIS: Oxidative stress among cervical cancer patients found to be increased and chemo-radiotherapy improved their anti-oxidant capacity.

Address for Correspondence/Yazıșma Adresi: Saiqa Shah, MD, Bhuvanesh Sukhlal Kalal, PhD,

Yenepoya (Deemed to be University), Yenepoya Medical College, Department of Biochemistry, Mangaluru, India

E-mail: : shah.saiqa2@gmail.com, bhuvanesh611@gmail.com ORCID ID: orcid.org/0000-0002-0639-5483,orcid.org/0000-0002-2560-3778

Received/Geliș Tarihi: 31.12.2018 Accepted/Kabul Tarihi: 27.05.2019

${ }^{\oplus}$ Copyright 2019 by Turkish Society of Obstetrics and Gynecology

Turkish Journal of Obstetrics and Gynecology published by Galenos Publishing House 


\section{Introduction}

Cervical cancer $(\mathrm{CaCx})$, the third most frequently occurring cancer among women worldwide, accounted for 266,000 deaths in 2012, $87 \%$ of which occurred in developing countries $^{(1)} . \mathrm{CaCx}$ is the leading cause of deaths related to cancer in India and accounts for $17 \%$ of all cancer deaths in women aged between 30 and 69 years. Taking current incidence rates into consideration, the annual load of fresh cases is expected to increase to 225,000 by 2025 in India ${ }^{(2,3)}$. The chances of surviving $\mathrm{CaCx}$ are considered as $42 \%$ in India ${ }^{(4)}$.

The most important causative agent is human papillomavirus (HPV), which spreads through sexual intercourse; males are the carriers in most cases, infecting and generating the disease in women. Many adults are unaware of HPV infection and its associated risks( ${ }^{(5)}$.

HPV causes $\mathrm{CaCx}$ by damaging DNA, but recent data revealed that oxidative stress plays a role in its development ${ }^{(6)}$. Chemoradiation is known to improve survival of patients with $\mathrm{CaCx}$. Oxidative stress is a shift of balance towards pro-oxidants in the prooxidant-antioxidant system. Free radicals are generated with a decrease in the levels of antioxidants, which leads to DNA damage, causing dysfunction and disease ${ }^{(7)}$. Severe oxidative stress causes DNA damage and mutations of tumor suppressor genes, initializing events in carcinogenesis, in addition, promoting multi-step carcinogenesis ${ }^{(7-9)}$.

Malondialdehyde (MDA) is a known marker of oxidative stress and antioxidant status in patients with cancer. The reactive oxygen species (ROS) produced by different processes initiate lipid peroxidation and lead to the production of excessive levels of MDA, which in turn changes the cellular function and leads to cancer formation ${ }^{(10)}$. The increase in MDA concentration can be attributed to a higher production of ROS due to the increased oxidative damage in patients with uterine cancer. As the disease progresses, the oxygen radical production also increases leading to increased lipid peroxidation. This results in cellular membrane degeneration and DNA damage ${ }^{(11)}$. The increase in free radical generation leads to excessive lipid peroxidation, indicated by a rise in serum MDA. Free radicals may cause evident changes to cell membrane function and the structural organization of DNA, thereby leading to mutations. Therefore, it can be stated that the product of lipid peroxidation could be one of the possible causes of uterine cancer progression ${ }^{(11,12)}$.

The total antioxidant capacity (TAC) measures the antioxidant capacity of whatever antioxidants are present in a biologic sample. It can be used as a dependable biomarker for the diagnosis, prognosis, and prevention of a large number of diseases $^{(13,14)}$.

Copper plays a pivotal role in the oxidant-antioxidant mechanism. The imbalance of copper leads to an increased susceptibility to oxidative damage. Copper acts as a prooxidant and may be involved in the formation of free radicals, catalyzed by metal ${ }^{(15)}$. Copper can interact directly with the bases of DNA at the sites of guanine and cytosine $e^{(16)}$. In vitro, the addition of copper to DNA mediates extensive DNA base damage inducing more mutations ${ }^{(17)}$. Copper also reacts with other free radical species such as hydroxide ion; therefore, the inactivation or loss of certain tumor suppressor genes can lead to the commencement and/or progression of carcinogenesis ${ }^{(16,17)}$. The elevation in copper concentrations may be due to the movement of copper from tissue to serum. Therefore, the present study evaluated the effect of chemoradiation on serum TAC, and MDA and copper concentrations in patients with $\mathrm{CaCx}$.

\section{Materials and Methods}

The prospective study was conducted between November 2013 and November 2015. Fifty patients with histopathologically proven $\mathrm{CaCx}$ who visited the Department of Oncology \& Gynaecology, at Vydehi Institute of Medical Sciences and Research Centre were recruited for the study. Subjects with any condition such as severe cardiovascular, respiratory diseases, diabetes mellitus, neurologic and psychiatric disorders, renal disorders and subjects on any medication such as oxidants vitamins, minerals, cigarette smokers, and alcoholics were excluded from the study.

Age-matched healthy women ( $\mathrm{n}=50)$ visiting the hospital for a routine health check-up and hospital staff members willing to participate in the study were included as healthy controls. Informed consent was obtained and approximately 3 $\mathrm{mL}$ of blood was collected before and after treatment (chemoradiotherapy). Serum was separated from the blood and stored at $-40{ }^{\circ} \mathrm{C}$ until required for analysis.

Chemotherapy was five cycles of cisplatin weekly in the dose of $40 \mathrm{~g} / \mathrm{m}^{2}$. Radiotherapy was brachytherapy with four fractions of 7 Gy each and two applications were one week apart.

In both groups, the TAC of serum was estimated using a FRAP assay (ferric reducing antioxidant power or the ferric reducing ability of plasma) according to the method of Benzie \& Strain, $1996^{(18)}$, MDA was measured using the method of Satoh ${ }^{(19)}$, and copper was measured using a modified spectrophotometric micro-method with guanidine hydrochloride ${ }^{(20)}$. In addition, these parameters were estimated in patients with $\mathrm{CaCx}$ before and after chemoradiation.

Ethical clearance was obtained from the institutional ethical committee of our institution prior to starting the study (reference no: VIMS \& RC/IEC/019/2013-14).

\section{Statistical Analysis}

The results were compiled in an excel spreadsheet, and frequency distribution and Bayesian analysis were performed using the SPSS v 16.0 software package (SPSS, Inc., Chicago, IL, USA). 


\section{Results}

In this study, 50 healthy controls and 50 patients with $\mathrm{CaCx}$ who fulfilled the eligibility criteria were included in the analysis. The subjects included in the study were females within the age group of 25-65 years. The average age of presentation among the patients was $43.98 \pm 6.38$ years (Table $1)$.

The mean serum copper concentration in the $\mathrm{CaCx}$ group and control group was $152.96 \pm 32.88 \mu \mathrm{g} / \mathrm{dL}$ and $104.88 \pm 24.45 \mu \mathrm{g} / \mathrm{dL}$, respectively. The mean serum TAC in the $\mathrm{CaCx}$ group and control group was $781.36 \pm 228.88$ $\mu \mathrm{mol} / \mathrm{L}$ and $1088.94 \pm 185.07 \mu \mathrm{mol} / \mathrm{L}$, respectively. The mean serum MDA concentration in the $\mathrm{CaCx}$ group and control group was $2.72 \pm 1.01 \mathrm{nmol} / \mathrm{mL}$ and $1.17 \pm 0.52 \mathrm{nmol} / \mathrm{mL}$, respectively. These results indicated that serum copper and MDA concentrations were significantly $(\mathrm{p}<0.001)$ increased in patients with $\mathrm{CaCx}$ when compared with the controls, and serum TAC was significantly $(\mathrm{p}<0.001)$ decreased in the patient group compared with the controls (Figure 1).

Serum values of TAC, MDA, and copper before andafter chemoradiation were $777.9 \pm 227.8 \mu \mathrm{g} / \mathrm{dL}, 2.7 \pm 1.0 \mu \mathrm{g} / \mathrm{dL}$, and

Table 1. Age distribution of healthy controls and cervical cancer $(\mathrm{CaCx})$ patients

\begin{tabular}{|c|c|c|c|c|}
\hline \multirow[t]{2}{*}{ Age (years) } & \multicolumn{2}{|c|}{$\begin{array}{l}\text { Healthy controls } \\
(\mathrm{n}=50)\end{array}$} & \multicolumn{2}{|c|}{$\begin{array}{l}\text { Cervical cancer } \\
\text { cases }(n=50)\end{array}$} \\
\hline & No & $\%$ & No & $\%$ \\
\hline $20-30$ & 25 & 50 & 1 & 2 \\
\hline $31-40$ & 18 & 36 & 14 & 28 \\
\hline $41-50$ & 7 & 14 & 25 & 50 \\
\hline $51-60$ & 0 & 0 & 10 & 20 \\
\hline Mean \pm SD & \multicolumn{2}{|c|}{$31.56 \pm 6.84$} & \multicolumn{2}{|c|}{$43.98 \pm 6.38$} \\
\hline
\end{tabular}

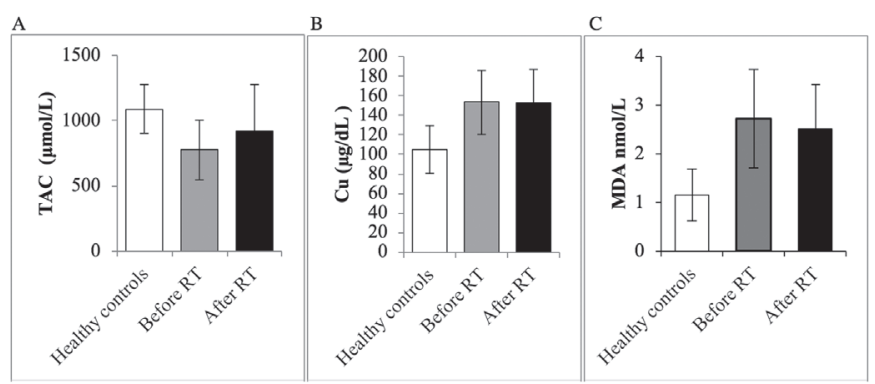

Figure 1. Serum total antioxidant capacity, malondialdehyde, and copper status of health controls and patients with cervical cancer before and after treatment

RT: Radiotherapy; data expressed as mean $\pm \mathrm{SD}$; **indicates $\mathrm{p}<0.001$; *indicates $\mathrm{p}<0.05$.

SD: Standard deviation, TAC: Total antioxidant capacity, MDA: Malondialdehyde, $\mathrm{Cu}$ : Copper
$153.2 \pm 32.6 \mu \mathrm{g} / \mathrm{dL}$, and $917.8 \pm 358.2 \mu \mathrm{g} / \mathrm{dL}, 2.5 \pm 0.92 \mu \mathrm{g} / \mathrm{dL}$, and $153 \pm 33.7 \mu \mathrm{g} / \mathrm{dL}$, respectively. Paired sample t-test analysis showed a significant increase and a decrease in TAC $(\mathrm{p}=0.018)$, and MDA ( $<<0.001)$, respectively, after chemoradiotherapy, whereas the changes in the concentrations of copper, were insignificant $(\mathrm{p}=0.405)$. There was a position correction of TAC with copper and MDA with copper (Figure 2).

\section{Discussion}

Exposure of cells to chemotherapy or radiotherapy causes the generation of free radicals and intracellular ROS, which induce cancer cell death. The present study was devised to evaluate and compare the serum values of TAC, MDA, and copper in patients with confirmed $\mathrm{CaCx}$ and normal healthy female subjects. There was a negative correlation between serum copper with TAC, and serum TAC with MDA, and a positive correlation between serum copper and MDA.

The role of oxidative stress in the causation of $\mathrm{CaCx}$ has been studied extensively. Factors determining the development and progression of $\mathrm{CaCx}$ include an imbalance between the detrimental effects of oxidative stress and the antioxidant defense system of the body. In our study, serum copper concentrations were studied in patients with $\mathrm{CaCx}$ because copper acts both as pro-oxidant and antioxidant.

Copper in its free, unbound form catalyzes the production of various toxic free radicals ${ }^{(15)}$. Elevated copper concentrations have the potential to produce a relatively continuous supply of free radicals and ROS formed within cells are highly reactive and are able to oxidize most of the biomolecules within the cell, leading to tissue injury and cancer. ROS have been associated for many years with oncogenesis; however, recently a new role has emerged for ROS as mediators of signaling pathways, leading to cell proliferation and tumor initiation and promotion ${ }^{(21)}$.

In our study, we obtained a significant $(\mathrm{p}<0.001)$ increase in serum copper concentrations in patients as compared with controls. Our results of high serum copper in patients with $\mathrm{CaCx}$ are also in agreement with several studies that found increased concentrations of serum copper in subjects with $\mathrm{CaCx}$ when compared with healthy controls ${ }^{(6,22-24)}$. Although, the cause of the increase in serum copper concentrations

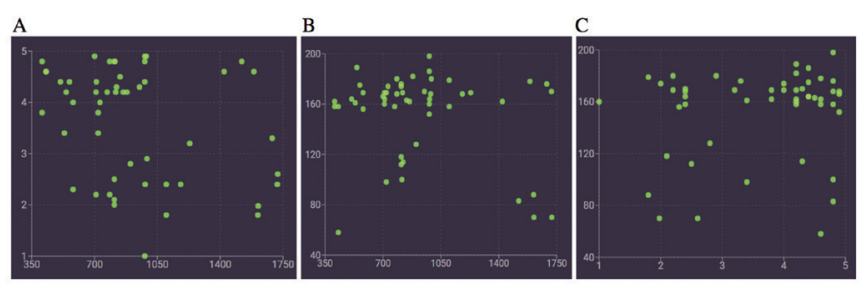

Figure 2. Correlation curve between: TAC-MDA (A), TAC-Cu (B), and MDA-Cu (C)

TAC: Total antioxidant capacity, MDA: Malondialdehyde, Cu: Copper 
among patients with cancer is not known, it was proposed to be related with the increased liver production of coppercontaining ceruloplasmin as an inflammatory response to cancer or from a tumor-induced decrease in the catabolism of the serum ceruloplasmin ${ }^{(22)}$. The meta-analysis by Zhang et al., ${ }^{(23)}$ showed significant evidence of higher serum copper concentrations in patients with $\mathrm{CaCx}$ than in controls, suggesting that serum copper exposure was a risk factor in $\mathrm{CaCx}$. The increased copper level could be related to the fact that copper is needed to form new blood vessels and because cancer needs them in order to grow ${ }^{(25)}$. Hence, the increase in copper values in patients with $\mathrm{CaCx}$.

The other finding of our study was a significant $(\mathrm{p}<0.001)$ decrease in serum TAC in patients as compared with controls. These results were in line with those of Demirci et al., (26) and Rong et al., (27) who reported the altered antioxidant status of patients with $\mathrm{CaCx}$ compared with healthy controls. However, Lee et al., ${ }^{(28)}$ stated that cervical intraepithelial neoplasia was also associated with lower blood antioxidant capacity levels. Kim et al., ${ }^{(29)}$ found that CIN was also associated with lower blood antioxidant capacity levels. The human body contains a complex antioxidant defense system that depends on the dietary intake of antioxidants as well as the endogenous production of anti-oxidative compounds such as glutathione ${ }^{(30)}$.

Antioxidants are cytoprotective chemicals that prevent oxidative damage caused by free radicals. ROS and nitrogen species, which are oxygen and nitrogen-derived free radicals, are generated naturally as by-products of cellular metabolism ${ }^{(15)}$. Under physiologic conditions, free radicals are immediately rendered inactive by antioxidants. However, in oxidative stress, these free radicals remain in excess and cause damage by reacting with macromolecules such as nucleic acids, proteins, polyunsaturated fatty acids, and carbohydrates ${ }^{(30)}$. Oxidative damage has been associated with the pathogenesis of many chronic medical disorders viz. atherosclerosis, cancer, arthritis, and neurodegenerative disorders ${ }^{(31)}$. DNA damage and abnormal DNA repairs are prime factors in the causation of cancer. Hence, the association between a low antioxidant level and various malignant and premalignant conditions has been assessed by researchers.

Further, we showed a significant increase $(p<0.001)$ in serum MDA concentrations in patients with $\mathrm{CaCx}$. Grace et al., ${ }^{(32)}$ estimated MDA in patients with $\mathrm{CaCx}$ to assess the extent of lipid peroxidation and found similar results of increased circulating levels of MDA. They attributed it to an increase in oxidative stress due to a deficiency of antioxidant mechanism. They also observed an increase in lipid peroxidation and a decline in enzymatic antioxidant status in patients with $\mathrm{CaCx}$. Naidu et al., ${ }^{(6)}$ also found increased levels of MDA and suggested that it was a possible cause in the progression of $\mathrm{CaCx}$. The same results of elevated MDA concentrations were found by Demirci et al., ${ }^{(26)}$ in patients with $\mathrm{CaCx}$ when compared with a control group. As per Demirici et al., (26) oxidative damage leads to the formation of products such as MDA, and DNA damage, which may, in turn, lead to mutagenesis, carcinogenesis, and cell death.

\section{Study Limitations}

There are some limitations in this study. This is a single centre hospital based study with small number of patients, the assessment of other oxidative enzymes, nutritional status are needed with larger patients size to get the solid evidence of antioxidants levels after receiveing the chemoradiotherapy.

\section{Conclusion}

The present findings demonstrate the imbalance in serum TCA, MDA, and copper among patients with $\mathrm{CaCx}$ when compared with healthy controls. These changes may play an important role in the pathogenesis and progression of $\mathrm{CaCx}$ through the involvement of these parameters in exaggerated oxidative stress. Further, chemoradiotherapy improved its anti-oxidant capacity. Extended studies are needed to evaluate the concurrent use of antioxidants with chemoradiotherapy for improving the disease prognosis.

Acknowledgment: We are thankful to the patients who gave their consent to conduct this study.

\section{Ethics}

Ethics Committee Approval: Ethical clearance was obtained from the institutional ethical committee of our institution prior to starting the study (reference no: VIMS \& RC/ IEC/019/2013-14).

Informed Consent: Informed consent was obtained.

Peer-review: Internally and externally peer-reviewed.

\section{Authorship Contributions}

Concept: S.S., Design: S.S., Data Collection or Processing: S.S., Analysis or Interpretation: S.S., B.S.K., Literature Search: S.S., B.S.K., Writing: B.S.K.

Conflict of Interest: No conflict of interest was declared by the authors.

Financial Disclosure: The authors declared that this study received no financial support.

\section{References}

1. Ferlay J, Soerjomataram I, Dikshit R, Eser S, Mathers C, Rebelo M, et al. Cancer incidence and mortality worldwide: sources, methods and major patterns in GLOBOCAN 2012. Int J Cancer 2015;136:E35986 doi:10.1002/ijc.29210.

2. Sreedevi A, Javed R, Dinesh A. Epidemiology of cervical cancer with special focus on India. Int J Womens Health 2015;7:405-14, doi:10.2147/IJWH.S50001.

3. Krishnan S, Madsen E, Porterfield D, Varghese B. Advancing cervical cancer prevention in India: implementation science priorities. Oncologist 2013;18:1285-97, doi:10.1634/ theoncologist.2013-0292.

4. Catarino R, Petignat P, Dongui G, Vassilakos P. Cervical cancer screening in developing countries at a crossroad: emerging 
technologies and policy choices. World J Clin Oncol 2015;6:28190, doi:10.5306/wjco.v6.i6.281.

5. Braaten KP, Laufer MR. Human papillomavirus (HPV), HPV-related disease, and the HPV vaccine. Rev Obstet Gynecol 2008;1:2-10.

6. M Smita K Naidu, AN Suryakar, Sanjay C Swami, RV Katkam, KM Kumbar. Oxidative stress and antioxidant status in cervical cancer patients. Indian J Clin Biochem: IJCB 2007;22:140-44, doi:10.1007/ BF02913333.

7. Georgescu SR, Mitran CI, Mitran MI, Caruntu C, Sarbu MI, Matei C, et al. New insights in the pathogenesis of HPV Infection and the associated carcinogenic processes: the role of chronic inflammation and oxidative stress. J Immunol Res 2018;5315816, doi:10.1155/2018/5315816.

8. De Marco F. Oxidative stress and HPV carcinogenesis. Viruses 2013;5:708-31, doi:10.3390/v5020708.

9. Kalal BS, Fathima F, Pai VR, Sanjeev G, Krishna CM, Upadhya D. Inhibition of ERK1/2 or AKT activity equally enhances radiation sensitization in B16F10 Cells. World J Oncol 2018;9:21-8, doi:10.14740/wjon1088w.

10. Ayala A, Muñoz MF, Argüelles S. Lipid peroxidation: production, metabolism, and signaling mechanisms of malondialdehyde and 4-hydroxy-2-nonenal. Oxid Med Cell Longev 2014;360438, doi:10.1155/2014/360438.

11. Barrera G. Oxidative stress and lipid peroxidation products in cancer progression and therapy. ISRN oncology 2012;137289, doi:10.5402/2012/137289.

12. Jelić M, Mandić A, Kladar N, Sudji J, Božin B, Srdjenović B. Lipid Peroxidation, Antioxidative Defense and Level of 8-Hydroxy2-Deoxyguanosine in Cervical Cancer Patients. J Med Biochem 2018;37:336-45, doi: https://doi.org/10.1515/jomb-2017-0053.

13. Cervellati C, Romani A, Seripa D, Cremonini E, Bosi C, Magon $\mathrm{S}$, et al. Systemic oxidative stress and conversion to dementia of elderly patients with mild cognitive impairment. BioMed Res Int 2014;309507, doi:10.1155/2014/309507.

14. Raghavendra U, Rao A, D'suoza J, Pai VR, Nair S, Kumar V, et al. Comparative estimation of salivary total antioxidant capacity in periodontal health and chronic periodontitis-a pilot study. Asian J Pharm Clin Res, AJPCR [Internet] 2018;11:523-5, doi:https://doi. org/10.22159/ajpcr.2018.v1li10.28409.

15. Viktorínová A, Toserová E, Krizko M, Duracková Z. Altered metabolism of copper, zinc, and magnesium is associated with increased levels of glycated hemoglobin in patients with diabetes mellitus. Metabolism 2009;58:1477-82, doi:10.1016/j. metabol.2009.04.035.

16. Govindaraju M, Shekar HS, Sateesha SB, Vasudeva Raju P, Sambasiva Rao KR, Rao KSJ, et al. Copper interactions with DNA of chromatin and its role in neurodegenerative disorders. J Pharm Anal 2013;3: 354-9, doi:10.1016/j.jpha.2013.03.003.

17. Lee DH, O'Connor TR, Pfeifer GP. Oxidative DNA damage induced by copper and hydrogen peroxide promotes CG-->TT tandem mutations at methylated CpG dinucleotides in nucleotide excision repair-deficient cells. Nucleic Acids Res 2002;30:3566-73.
18. Benzie IF, Strain JJ. The ferric reducing ability of plasma (FRAP) as a measure of "antioxidant power": the FRAP assay. Anal Biochem 1996;239:70-6, doi:10.1006/abio. 1996.0292.

19. Satoh, K. Serum lipid peroxide in cerebrovascular disorders determined by a new colorimetric method. Clin Chim Acta 1978;90:37-43.

20. Prakash M, Shetty JK. A modified spectrophotometric micromethod to determine serum copper. Asian J Biochem 2008;3:38-42, doi:http://dx.doi.org/10.3923/ajb.2008.38.42.

21. Kumari S, Badana AK, G MM, G S, Malla R. Reactive oxygen species: a key constituent in cancer survival. Biomark Insights 2018;13:1177271918755391. doi: 10.1177/1177271918755391.

22. Coates RJ, Weiss NS, Daling JR, Rettmer RL, Warnick GR. Cancer risk in relation to serum copper levels. Cancer Res 1989;49:4353-6.

23. Zhang M, Shi M, Zhao Y. Association between serum copper levels and cervical cancer risk: a meta-analysis. Biosci Rep 2018;38, doi:10.1042/BSR20180161.

24. Cunzhi H, Jiexian J, Xianwen Z, Jingang G, Shumin Z, Lili D. Serum and tissue levels of six trace elements and copper/zinc ratio in patients with cervical cancer and uterine myoma. Biol Trace Elem Res 2003;94:113-22, doi:10.1385/BTER:94:2:113.

25. Urso E, Maffia M. Behind the link between copper and angiogenesis: established mechanisms and an overview on the role of vascular copper transport systems. J Vasc Res 2015;52:172-96, doi:10.1159/000438485.

26. Demirci S, Ozsaran Z, Celik HA, Aras AB, Aydin HH. The interaction between antioxidant status and cervical cancer: a case control study. Tumori 2011;97:290-5, doi:10.1700/912.10024.

27. Rong Wu, Jiafu F, Yuwei Y, Chunmei D, Anyang L, Jie L, et al. Significance of serum total oxidant/antioxidant status in patients with colorectal cancer. PloS One 2017;12:e0170003, doi:10.1371/ journal.pone.0170003.

28. Lee GJ, Chung HW, Lee KH, Ahn HS. Antioxidant vitamins and lipid peroxidation in patients with cervical intraepithelial neoplasia. J Korean Med Sci 2005;20:267-72, doi:10.3346/jkms.2005.20.2.267.

29. Kim SY, Kim JW, Ko YS, Koo JE, Chung HY, Lee-Kim YC. Changes in lipid peroxidation and antioxidant trace elements in serum of women with cervical intraepithelial neoplasia and invasive cancer. Nutr Cancer 2003;47:126-30, doi:10.1207/s15327914nc4702_3.

30. Kurutas EB. The importance of antioxidants which play the role in cellular response against oxidative/nitrosative stress: current state. Nutr J 2016;15:71, doi:10.1186/s12937-016-0186-5.

31. Rathan Shetty KS, Kali A, Rachan Shetty KS. Serum total antioxidant capacity in oral carcinoma patients. Pharmacognosy Res 2015;7:1847, doi:10.4103/0974-8490.150513.

32. Grace JN, Narendhirakannan RT. Detection and genotyping of highrisk HPV and evaluation of anti-oxidant status in cervical carcinoma patients in Tamil Nadu State, India--a case control study. Asian Pac J Cancer Prev 2011;12:2689-95. 